\title{
Reimagining Multilateralism: A Long but Urgently Necessary Journey
}

\author{
Stefano Prato ${ }^{1}$ Barbara Adams ${ }^{2}$
}

Published online: 20 October 2021

(c) Society for International Development 2021

Exploring the issue of governance in the current global conjuncture is a particularly challenging task. On one hand, the widespread reality of global vaccine apartheid shows the failure of governance to respond to the current circumstances with the necessary human rights and equality/equity focus. On the other, the dynamics at play are so entrenched in deep power asymmetries and political economies that related efforts towards constructive positive agendas are depicted as exercises of futility and wishful thinking.

The multiple crises ignited by the COVID-19 pandemic have exposed and magnified the depth of inequalities within and between countries. Decades of hyper-globalization have led to extensive de-regulation, financialization and corporate concentration and reinforced an international division of labour that relegates developing countries to the lower end of the global economic system. The pandemic also disproportionately impacted women and exposed the unresolved crisis of care, which continues to rely predominantly on women's unpaid and underpaid domestic and care work in the household as well as in the health, food and informal sectors, amounting to a huge, and often countercyclical, subsidy to the global economy. It reinforced the urgent need to confront the escalating incidence of gender-based violence and to redirect resources to strengthen public services and social protection systems. This urgency highlighted the impact of the decades-long pursuit of fiscal austerity, privatization and public-private partnerships-all of which have weakened state capacities to ensure the realization of human rights and pursue effective sustainable development pathways. In this context, many developed countries continue to deploy large stimulus packages and extensive vaccination programmes, while many developing countries, particularly African and Least Developed Countries-suffocated by illicit financial flows, unfair trade and investment regimes, unsustainable

Stefano Prato

stefanop@ sidint.org

Society for International Development, Rome, Italy

2 Global Policy Forum, New York, USA debt burdens and policy conditionalities-confront massive restrictions on policy and fiscal space that narrow their capacity to focus on rights-based socio-economic transformation strategies.

\section{A Problem that Comes from Far}

The separation from aspirational development discussions among UN Member States and economic governance decisions within restricted developed country clubs is not new. After extensive negotiation on a new development agenda through the series of UN Conferences in the 1990s, the Group of 77 called on the 2002 International Conference on Financing for Development (United Nations 2002) to initiate a process of democratization of global economic governance aimed at removing the systemic obstacles to the socioeconomic transformation of developing countries. Unfortunately, this process-while keeping open a critical window for economic governance within the United Nations-has remained largely aspirational, while the power of developed countries' organizations continues to strengthen, especially since the emergence of the G20 as a critical space for economic coordination among the most powerful economies.

The UN Conference on Environment and Development gave impulse to and launched three binding Conventions on Biodiversity, Climate Change and Desertification (United Nations 1992) that continue to frame international policymaking on these critical domains. However, and despite other important normative binding achievements such as the UN Convention on the Rights of Persons with Disabilities (United Nations 2006), too many UN processes have relied on non-binding political commitments. These have contributed to an emerging body of soft law, which remains critical to building global policy convergence on globally agreed objectives but is often incapable of confronting the normative hierarchy of binding economic agreements, such as those on trade and investments negotiated in the World Trade Organization (WTO). In this context, developed countries continue to obstruct efforts within the UN to advance 
critical decisions such as a legally binding instrument to regulate, in international human rights law, the activities of transnational corporations and other business enterprises. Against the calls by developing countries to democratically establish, under the aegis of the UN, a global tax convention to tackle tax avoidance as well as a sovereign debt work mechanism to address the debt crisis, developed countries have reasserted their unwillingness to address these matters in normative spaces where developing countries have equal vote and rather decide within their own institutions. The recent $\mathrm{OECD} / \mathrm{G} 20$ decision on minimum tax rates for multinational corporations (OECD 2021) —widely seen as 'the deal of the rich' (GATJ 2021) - is a perfect example.

At the same time, the United Nations has remained the critical space for security-related discussions and decisions, however anchored in the two-tier post war power structure of the UN Security Council. This 'veto-centric' power arena, together with the relentless shift from long-term human rights and development support to humanitarian, disaster and conflict assistance shows there is still a long way to go to advance real democratization of economic governance.

\section{The COVID-19 Crisis: The (Usual) Winners Take All}

Contrary to the widespread sentiments within progressive circles that the COVID-19 crisis could offer opportunities to re-imagine our dystopian realities, the crisis has further exacerbated the concentration of political and economic power within the same few hands (Adams and Martens 2021).

COVID-19, by imposing virtual discussions and negotiations, provided greater leverage to all those actors promoting the reduction of the UN to a symbolic space, dominated by lofty statements and limited decision-making. The 2020-21 period has witnessed the highest number of interventions by Heads of State/Heads of Government ever. However, these have mostly been pre-recorded statements while actual negotiations on critical matters of substance have stalled. The participation of civil society, which was already suffering significant challenges prior to the pandemic, was equally turned into a staged exercise, with real substantive contributions to the policy process being minimized if allowed at all.

The theatrical and largely symbolic nature of the UN discussions facilitated (as well as reflected) the increased power of developed countries within the institutions they dominate, with special reference to the G7/G20 process, the OECD and the Bretton Woods Institutions (BWI). Beyond rhetoric, developed countries' responses to the crisis were largely a combination of 'our interests first' and 'we know best' attitudes, particularly in the mix of global health responses and economic recovery packages. The latest discussion within the G20 on the possible establishment of a Global Health (Threats) Board supported by a World Bank-managed Global Health (Threats) Fund, is a good example of the consolidation of a model of global governance based on the full control of the powerful. Persistent vaccine apartheid, including the continued resistance to approving a waiver that would allow countries to forgo some elements of the Agreement on Trade-Related Aspects of Intellectual Property Rights (TRIPS) to speed up the production of vaccines, diagnostics and therapeutics, vividly illustrates this reality.

Theatrical virtual multilateralism together with decisions increasingly concentrated in developed counties' institutions is reinforced by the continued pressure on the United Nations to embrace multi-stakeholder governance mechanisms, which may compromise the independence, integrity and trustworthiness of policymaking and reframe governance away from duty-bearer responsibilities in favour of powerful interests. The latest recommendation by the UN Interagency Coordination Group on antimicrobial resistance (AMR) to establish the AMR Multi-Stakeholder Partnership Platform is a perfect case in point. This is the 'Great Reset' proposed by the World Economic Forum (WEF 2020), which casts a dark shadow on the memorandum of understanding (MoU) signed by UN Secretary-General António Guterres and the World Economic Forum in June 2019 , framing a strategic partnership between the two institutions. Many civil society voices raised deep concerns about this partnership and requested the Secretary-General to cancel the agreement (TNI 2019). Unfortunately, the preparatory process of the 2021 UN Food Systems Summit well exposed the implications of an opaque and confused multi-stakeholder governance architecture-where no single intergovernmental legitimate decision was ever taken-in terms of corporate capture, misleading narratives and false solutions. The process led by powerful proponents of the corporate-dominated global industrial food system generates outcomes that neither serve peoples and their communities nor developing countries, precisely when the same proponents have obstructed proper policy decisions and initiatives by the UN Committee on World Food Security (CFS) to confront the COVID-19 induced food crisis.

\section{Reimaging Multilateralism}

It is easy to conclude that the current practice of multilateralism has failed. Many of the articles in this Journal illustrate this and unpack it in varying degrees and from different angles. They also explore needed changes ranging from how to rehabilitate the present set-up (Montes 2021) to exploring another vision entirely (Durano 2021) and many versions in-between. 
It is not easy to move from the present reality to a new multilateral world. All too often steps undertaken with the aim and ambition of transformation are stalled or sidetracked by the very interests that shape the (negative/failed) reality.

Yet this step-by-step pragmatism is the preferred approach of many of the institutions of multilateralism and global governance, not equipped or prepared to recognize their own limits, and unable to free themselves from their governors, their mandates or their own mindsets. This applies particularly to the Bretton Woods Institutions, relentlessly pursuing policy change through financing strategies/policies and funding controls; and the WTO, set up to bind states together through trade and investment with no regard for the power of the external market - for goods, for services, for investment flows.

Does it also apply to the UN itself and the system that has grown up around it? Unlike the BWIs and the WTO, its mandate and purpose are peace and justice, sustainability, human rights and human beings. However, its 'governors' do not hold the institution accountable to its mandate. Rather the one dollar, one vote mentality has also permeated its departments, agencies and programmes, mainly through horrendous financing gaps that have developed from a decades-old over-dependence on voluntary allocations of official development assistance. After the era of de-colonization, this dependence has steadily skewed its programming to focus on humanitarian, disaster and conflict situations, away from human rights, sustainable development and democratic economic governance.

Can it go back to the basics of democratic global governance_-reset to be relevant for today's global challenges, including the regulatory challenges of transnational corporations, the ossification of inequalities between countries and the existential climate imperative? Doing so would require many supporters of multilateralism to be more rigorous about the NATURE and quality of multilateralism, not just to wave its flag (Adams 2020).

Multilateralism has been corrupted and efforts justified in its defence are often undermining it further and alienating and driving away its champions. The defenders accept weak consensus to ensure the inclusion of the most reluctant and in so doing accept outcomes that are viewed as irrelevant or inefficient. The resulting multilateralism fatigue and/or trust gap is filled with an array of initiatives populated by self-selected 'partners', parochial accountability models and unreliable funding ideas. This multi-stakeholder hodgepodge further fragments global governance, relying as it does on volunteerism and the wooing of the most powerful actors in the public and private spheres.
This edition of the Journal is a contribution to shaking us out of this circular downward spiral 'cul-de-sac' mentality. Rather than going in circles and further fuel endless policy debates, its contributors focus on the need for systemic change-away from the current model that extracts wealth, exploits labour and amplifies inequalities - to continue the struggle for decolonization, not only of territory but also of decision-making processes that span individual, institutional, domestic and cross border realities.

It is going to be a long way home, but starting the journey remains an urgent imperative.

\section{References}

Adams, Barbara. 2020. Chapter 3.7 - Re-inventing multilateral solidarity: rhetoric, reaction or realignment of power? Shifting policies for systemic change, Spotlight on Sustainable Development. https:// www.2030spotlight.org/en/book/2040/chapter/chapter-37-re-inven ting-multilateral-solidarity-rhetoric-reaction-or-realignment.

Adams, Barbara and Jens Martens. 2021. Diverging recovery - deepening inequalities, Demanding justice beyond rhetoric, Spotlight on Sustainable Development. https://www.2030spotlight.org/en/book/ 2495/chapter/chapter-1-diverging-recovery-deepening-inequalities.

Durano, Marina. 2021. Negotiating Boundaries of Power in the Global Governance for Care. Development. https://doi.org/10.1057/ s41301-021-00283-3.

Global Alliance for Tax Justice (GATJ). 2021. The OECD-led Tax Deal Will only Deepen Inequalities in and Between Countries https:// www.globaltaxjustice.org/en/latest/oecd-led-tax-deal-will-onlydeepen-inequalities-and-between-countries. Accessed 10 October 2021.

Montes, Manuel F. 2021. Slaying the New Dragons that Threaten Peace: Renewing the UN's 'Systemic Issues' Agenda. Development. https:// doi.org/10.1057/s41301-021-00300-5.

OECD. 2021. Statement on a Two-Pillar Solution to Address the Tax Challenges Arising from the Digitalisation of the Economy-8 October. Paris, OECD https://www.oecd.org/tax/beps/statementon-a-two-pillar-solution-to-address-the-tax-challenges-arisi ng-from-the-digitalisation-of-the-economy-october-2021.htm. Accessed 10 October 2021.

TNI. 2019. End the United Nations/World Economic Forum Partnership Agreement. https://www.tni.org/en/article/end-the-unitednationsworld-economic-forum-partnership-agreement. Accessed 10 October 2021.

United Nations. 2006. UN Convention on the Rights of Persons with Disabilities. New York: United Nations.

United Nations. 2002. Monterrey Consensus on Financing for Development. New York: United Nations.

United Nations. 1992. Rio Declaration and Agenda 21. New York: United Nations.

World Economic Forum (WEF). 2020. The Great Reset https://www. weforum.org/great-reset/. Accessed 10 October 2021.

Publisher's Note Springer Nature remains neutral with regard to jurisdictional claims in published maps and institutional affiliations. 